\title{
MENINGKATKAN KETERAMPILAN MOTORIK HALUS ANAK MELALUI KEGIATAN PEMBELAJARAN MEMBATIK MENGGUNAKAN MEDIA TEPUNG PADA ANAK KELOMPOK B PAUD AISYIYAH III KOTA BENGKULU
}

\author{
Khoiriyah Ikawati \\ Khoiriyahlkawati@gmail.com \\ Sri Saparahayuningsih \\ saparahayuningsih@unib.ac.id \\ Yulidesni \\ yulidesni@gmail.com
}

\begin{abstract}
The problem in this research is Whether through the learning activities of batik using media power can improve the fine motor skills of children in group B PAUD Aisyiyah III Kota Bengkulu. The aim of this classroom action research was to improve motor skills development through media power activity in group B PAUD Aisyiyah III Kota Bengkulu. This was a classroom action research (CAR). In this research it was proven that throught the learning activities of batik using media power development on cycle I reached the mean score of 2,175 with classical mastery of $44 \%$ which categorized as less criteria, on cycle II reached the mean score of 3,0 with classical mastery of $60 \%$ which categorized as enough criteria, then on cycle III the the mean score 4,325 with classical mastery of $86,5 \%$ which categorized good criteria.
\end{abstract}

Keywords: Fine motor, Batik Learning Activities, Media Power.

\section{PENDAHULUAN}

Melihat fenomena yang terjadi di lapangan khususnya di PAUD Aisyiyah III Kota Bengkulu berdasarkan pengamatan menunjukan bahwa anak-anak pada umumnya memiliki keterampilan motorik halus yang masih rendah. Dari 10 anak yang masih kurang motorik halusnya ada 8 anak. Seperti ketika anak menulis namanya sendiri yang masih coret-coretan, menjiplak bentuk atau garis, kesulitan membuat bentuk-bentuk tulisan yang masih terlihat coret-coret, keterampilan anak dalam memegang sesuatu masih belum kuat dan belum tepat serta kegiatan lain yang masih memerlukan bimbingan.

Sejalan dengan pendapat Hurlock dalam Paraswati (2013:3) bahwa "penguasaan motorik halus penting bagi anak, karena seiring makin banyak keterampilan motorik yang dimiliki semakin baik pula penyesuaian sosial yang dapat dilakukan anak serta semakin baik prestasi di sekolah". Pengembangan motorik pada anak usia dini merupakan bagian dari kebutuhan yang sangat diperlukan dalam kehidupan sehari-hari, terutama dalam melatih otot-otot kecil anak serta untuk mengkoordinasi tangan dan mata pada anak.

Motorik halus dapat dilatih dan dikembangkan melalui kegiatan dan stimulasi yang tepat sesuai dengan tingkat usia perkembangan anak. Seperti bermain puzzle, menyusun balok, membuat garis, melipat kertas, kolase, menggunting, meronce, menggambar, menjahit, dan membatik. Salah satu kegiatan yang dapat dilakukan dalam mengembangkan motorik halus anak yaitu melalui kegiatan pembelajaran membatik.

Sejalan dengan pendapat Yamin (2013:101) yang menyatakan bahwa keterampilan motorik halus anak ada 
empat macam yaitu menjimpit, memegang, konsentrasi dan koordinasi mata dan tangan. Dapat dikatakan bahwa kegiatan membatik sangat berpengaruh terhadap keterampilan motorik halus anak usia dini.

Untuk mengoptimalkan partumbuhan dan perkembangan anak usia dini, salah satu teknik yang dijadikan materi pembelajaran di PAUD Aisyiyah III Kota Bengkulu adalah pembelajaran membatik dengan tepung. Digunakan media tepung karena membatik dengan tepung mempunyai kelebihan yaitu anak akan tertarik karena tepung biasanya digunakan untuk membuat kue, Membatik dengan tepung juga sangat aman, tidak berbahaya, harga terjangkau, dan lebih mudah untuk anak dalam melakukan kegiatan pembelajaran membatik. Media tepung juga memiliki kekurangan yaitu membatik dengan tepung memerlukan ketekunan, keuletan karena tepung yang telah kering mudah retak. Membatik dengan tepung juga akan melibatkan otot, syaraf otak dan jari-jemari tangan. Anak akan belajar memegang dan menjimpit, sehingga dapat meningkatkan kelenturan jari anak.

Berdasarkan latar belakang yang telah dikemukakan, rumusan masalah secara umum dalam penelitian ini yaitu Bagaimana kegiatan membatik dengan media tepung dapat meningkatkan keterampilan motorik halus anak? Apakah melalui kegiatan membatik dengan media tepung dapat meningkatkan keterampilan motorik halus anak?

Berdasarkan pendapat Sumantri (2005:143) menyatakan bahwa motorik halus adalah pengorganisasian penggunaan sekelompok otot-otot kecil seperti jarijemari dan tangan yang sering membutuhkan kecermatan dan koor-dinasi dengan tangan yang menggunakan alat-alat untuk mengerjakan suatu objek.

Menurut pendapat Yamin (2013: 101) mengungkapkan aspek keterampilan motorik halus ada lima macam yaitu menggenggam, menjimpit, memegang, merobek, menggunting, dan koordinasi mata dan tangan. Keteram-pilan motorik halus anak dapat dilatih dan dikembangkan melalui kegiatan pembelajaran membatik menggunakan media tepung. Melalui aspek memegang dan menjimpit, yang meliputi empat kriteria penilaian yaitu koordinasi mata dan tangan, konsentrasi, kekuatan, dan kelenturan.

Menurut Handoyo (2008:3) menyatakan bahwa "kata batik dalam bahasa Jawa berasal dari kata tik. Kata itu mempunyai pengertian berhubungan dengan suatu pekerjaan halus, lembut dan kecil yang mengandung keindahan". Menurut kartika (2015:95) Menjelaskan bahwa membatik merupakan bagian dari pembelajaran melukis. Kegiatan membatik yaitu memberi warna dengan menggunakan sehelai kain putih sebagai alat melukis dipakai canting dan sebagai bahan melukis dipakai cairan malam. Sedangkan menurut Rahayu dalam Larasati (2015:5) menyatakan bahwa membatik bagi anak usia dini adalah mengoleskan perintang pada kain atau media pengganti kain sebelum diberi warna.

Menurut Prasetyono

(2008:139) manfaat kegiatan membatik untuk anak usia dini yaitu kegiatan ini bagus untuk koordinasi mata dan tangan, keterampilan tangan, dan belajar untuk mengerjakan tugas hingga mencapai hasil yang diinginkan. Kegiatan ini akan menciptakan pola-pola yang sangat menarik, dan akan memberikan kepercayaan diri pada anak.

Berdasarkan pendapat yang dikemukakan, maka penelitian ini menggunakan media tepung untuk meningkatkan keterampilan motorik halus anak. Membatik untuk anak usia dini yaitu membuat gambar/corak yang dihasilkan menggunakan tepung yang dilakukan dengan pemberian warna menggunakan kuas diatas sehelai kain putih yang dilakukan secara lembut dan perlahan. 
Media tepung mempunyai kelebihan yaitu dengan menggunakan media tepung akan lebih aman, nyaman, harga terjangkau, dan tidak berbahaya. Melalui kegiatan membatik menggunakan media tepung dapat meningkatkan keterampilan motorik halus anak sebagai kesiapan anak dalam menulis.

\section{METODE}

Metode yang digunakan pada penelitian ini adalah Penelitian Tindakan Kelas (PTK), pelaksanaan penelitian tindakan kelas ini dilaksanakan pada kelompok B PAUD Aisyiyah III Kota Bengkulu, yang dilaksanakan selama tiga siklus, disetiap pertemuan dilaksanakan selama tiga kali pertemuan. Penelitian Tindakan Kelas (PTK) ini dirancang berdasarkan pendapat Arikunto (2010:3) melalui tahapan kegiatan yaitu perencanaan, pelaksanaan, observasi, dan refleksi. Teknik pengumpulan data yang digunakan dalam penelitian ini menggunakan metode observasi sehing-ga instrumen pengumpulan data yang digunakan adalah lembar observasi siswa dan lembar observasi guru. Teknik analisis data dalam penelitian ini mengg-unakan analisis data dengan uji nilai statistik dan ketuntasan belajar menurut pendapat Aqib (2009:204-205).

Alat dan bahan yang dibutuhkan dalam kegiatan pembelajaran membatik yaitu: Tepung, air, pewarna makanan (pasta), Kain katun, kertas padi, lakban, Kuas kaku, wantex, Cup gelas plastik.

\section{HASIL DAN PEMBAHASAN}

Hasil dari penelitian keterampilan motorik halus anak melalui kegiatan pembelajaran membatik menggunakan media tepung pada siklus III mencapai hasil nilai rata-rata sebesar 4,325 dengan kriteria baik dengan ketuntasan klasikal yaitu 86,5 yang mencapai ketuntasan belajar yaitu 75\%. Hal ini terjadi karena peningkatan pada tiap siklusnya. Pada siklus I pertemuan pertama sampai pertemuan ketiga memperoleh hasil rata-rata nilai keseluruhan yaitu 2,17 dengan kriteria kurang. Dan hasil ketuntasan belajar anak secara klasikal sebesar 44\% (belum tuntas). Dari hasil refleksi yang diperoleh pada siklus I, peneliti dan teman sejawat memerlukan perbaikan karena belum mencapai ketuntasan belajar yaitu $75 \%$, sehingga peneliti melanjutkan pada siklus selanjutnya yaitu siklus II. Pada siklus II pertemuan pertama sampai pertemuan ketiga memperoleh hasil rata-rata nilai keseluruhan yaitu 3,0 dengan kriteria cukup. Dan hasil ketuntasan belajar anak secara klasikal sebesar $60 \%$ (belum tuntas). Dari hasil refleksi yang diperoleh pada siklus I dan siklus II, peneliti dan teman sejawat memerlukan perbaikan karena belum mencapai ketuntasan belajar yaitu $75 \%$, sehingga peneliti melanjutkan pada siklus selanjutnya yaitu siklus III. Pada siklus III pertemuan pertama sampai pertemuan ketiga memperoleh hasil rata-rata nilai keseluruhan yaitu 4,325 dengan kriteria baik. Dan hasil ketuntasan belajar anak secara klasikal sebesar 86,5\%. Dari hasil refleksi yang diperoleh pada siklus III menunjukkan bahwa telah mencapai ketuntasan belajar yaitu $75 \%$.

Berdasarkan hasil pengamatan tiap siklus, dapat diketahui bahwa mela-lui kegiatan pembelajaran membatik de-ngan media tepung dapat meningkatkan keterampilan motorik halus anak dan memberi manfaat yang sangat baik. Hal ini sesuai dengan pendapat Prasetyono (2008:139) mengemukakan bahwa manfaat kegiatan pembelajaran membatik untuk anak usia dini yaitu kegiatan ini bagus untuk koordinasi mata dan tangan, keterampilan tangan sebagai kesiapan anak dalam menulis dan belajar untuk mengerjakan tugas hingga mencapai hasil yang diinginkan. Kegiatan ini akan menciptakan pola-pola yang sangat 
menarik, dan akan memberikan kepercayaan diri pada anak.

\section{KESIMPULAN}

Berdasarkan hasil penelitian yang telah dilakukan pada anak kelompok B PAUD Aisyiyah III Kota Bengkulu dapat disimpulkan bahwa Melalui kegiatan pembelajaran membatik menggunakan media tepung dapat meningkatkan keterampilan motorik halus anak dengan ketuntasan sebesar $86,5 \%$ yang meliputi aspek memegang dan menjimpit melalui empat kriteria yaitu koordinasi mata dan tangan, konsentrasi, kekuatan, dan kelenturan yang dapat meningkatkan aspek perkembangan anak dengan baik.

\section{SARAN}

Saran yang diberikan pada penelitian ini yaitu untuk peneliti lebih lanjut dapat melakukan penelitian ten-tang keterampilan motorik halus melalui kegiatan pembelajaran membatik dengan kegiatan lainnya misalnya dengan teknik mengecap menggunakan bahan dari tumbuhan. Saran bagi guru/pendidik yaitu melalui pembe-lajaran membatik ini diharapkan dapat diterapkan guru dalam mengembangkan potensi yang dimiliki oleh anak dan dapat mendukung proses pembelajaran yang lebih bermakna bagi anak.

\section{DAFTAR PUSTAKA}

Arikunto, 2010. Penelitian Tindakan Kelas. Jakarta: Bumi Aksara.

Aqib, dkk. 2009. Penelitian Tindakan Kelas Untuk Guru SD, SLB, dan TK. Bandung: CV Yrama Widya.

Handoyo, Joko Dwi. 2008. Batik dan Jumputan. Yogyakarta: PT Macan Jaya Cemerlang

Prasetyono, Dwi Sunar. 2008. Biarkan Anakmu Bermain. Jogjakarta: Diva Press.
Paraswati, Era. 2013. Membatik Dengan Tepung Untuk Meningkatkan Keterampilan Motorik Halus Anak Di Tk Negeri Pembina Yogyakarta.skripsi. Yogyakarta: Universitas Negeri Yogyakarta. Fakultas Bahasa Dan Seni

Sumantri. 2005. Model Pengembangan Keterampilan Motorik Anak Usia Dini. Jakarta: Departemen Pendidikan Nasional

Yamin, Marinis, Sanan, Jamilah Sabri, 2013. Panduan PAUD Pendidikan Anak Usia Dini. Jakarta: Gaung Persada Press Group. 